\title{
Roof-mounted photovoltaic generator temperatue modeling based on common brazil roofing materials
}

\author{
Bernardo de Souza Guimarães ${ }^{1}\left(\mathbb{D}\right.$, Lucas Farias $^{1}$, Delly Oliveira Filho ${ }^{2}$, Lawrence Kazmerski ${ }^{3}$, \\ and Antonia Sônia A . Cardoso Diniz ${ }^{1, *}$ (D) \\ ${ }^{1}$ GREEN Solar-IPUC, PPGEM, Graduate Programme of Mechanical Engineering, Pontifícia Universidade Católica de Minas \\ Gerais (PUCMinas), Belo Horizonte, Brazil \\ ${ }^{2}$ Universidade Federal de Viçosa, Viçosa, Minas Gerais, Brasil \\ ${ }^{3}$ University of Colorado Boulder, RASEI, Boulder, Colorado, USA
}

Received: 10 July 2021 / Received in final form: 5 November 2021 / Accepted: 6 November 2021

\begin{abstract}
This paper examines the performance of solar photovoltaic generators on roofs of residential buildings. The primary focus is the loss of performance due to temperature increase as function of roof material and the distance from the photovoltaic (PV) generator to the roof. A heat transfer model has been developed to predict PV module temperature, and the equations of the model were solved using the Engineering Equation Solver (EES) software. The research modeling correlates the distance of the solar generator to the roof and the roofing material with the temperature variations in the PV generator. There are many models to predict PV module temperature, but this study refines the prediction by the distance from PV module to roof and the roofing material as variables. Optimal combinations of distance and materials that minimize the heating loss in the solar generator leading to increased electrical power generation. Results show an average error of $3 \%-4 \%$ from the temperature predicted by the model to the temperature measured under experimental conditions in Belo Horizonte, Brazil. The minimum roof-module separation required to ensure minimal PV performance loss from heating from the roof is $\sim 10 \mathrm{~cm}$ for red ceramic and cement fiber roofs. For galvanized steel, the optimal distance is between $20 \mathrm{~cm}$ and $30 \mathrm{~cm}$. Cement fiber shows the best predicted and measured characteristics for PV-panel roof mounting among the 3 -common commercial roofs evaluated in these studies. These investigations were based on roof installations and local materials in Belo Horizonte, Brazil.
\end{abstract}

\section{Introduction}

Cumulative PV installations in Brazil reached $8 \mathrm{GW}$ at the end of 2020, and the country has a solar-PV target of at least $90 \mathrm{GW}$ by 2050 [1]. Though the focus has been on large power-plant installations, the interest and investment in rooftop PV systems has been increasing. Like many other countries, Brazil is now experiencing some issues relating to proper installations and certification. Many systems are under-performing because they have either been improperly installed or were designed for other climates or roofing configurations and materials [2-8]. On the environmental and location sides we have to consider potentially negative performance factors including soiling [9-15], shading $[14,16,17]$, cell/module aging [18-20], damage to due handling [21], climate and ambient temperatures [22,23].

\footnotetext{
* e-mail: asacd@pucminas.br
}

This study evaluates the installation of PV rooftop systems in the Brazil environment, based on common Brazil roofs, materials, and configurations. The study incorporates crystalline-Si PV modules in the modeling and analysis Figure 1 shows two examples of PV generators over typical brazilian roofs.

The PV module performance has been represented by several models aimed at increasing system power output. Various authors have modelled the critical PV module temperature and its relation to meteorological conditions [22-30], primarily through considering thermal radiation, convection, and conduction mechanisms relating to the power generated. For example, Armstrong et al. [31] studied an overall thermal response as a function of loss coefficient, resulting in a linear relationship between module temperature and irradiance under steady-state conditions. Tuncel et al. [32] describes a transient thermal model, which considers hourly meteorological data, wind speed and direction, module parameters, and locational information. In developing this work, he used the first law 

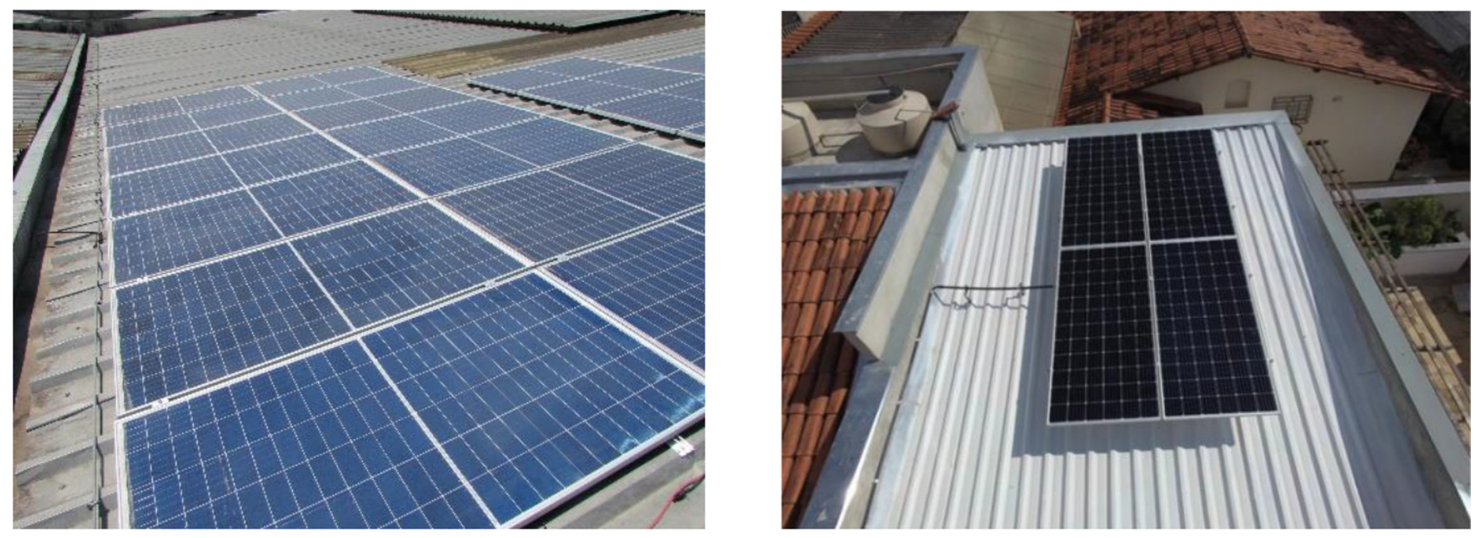

Fig. 1. Examples of Brazil PV roof installations on galvanized steel roofing material.

of thermodinamics, avaiable data from PV module manufacturers, and the heat capacity of the PV module. The energy balance is the key feature of this approach. Torres lobera [33] also uses the energy balance leading to a dynamic thermal model.

Most of PV module temperature models are based on two simple parameters: solar irradiance and ambient temperature. These are the most important factors that directly affect the PV module temperature. But these are couple with the location and environment and difficult to control. However, the PV generator installation can be controlled in most cases. Skoplaki and Palivos [34] take in to account the installation factors in their temperature model. They defined 4 coefficients associated to 4-types of installations, depending whether the PV module is free or ground mounted, installed on a flat roof, installed on a tilted roof, or integrated to the roof structure.

Modeling and simulation of a roof-mounted PV system is important for optimizing real PV module powergeneration and for forecasting of a systems capability [7]. The objective and major contributions of current work are modeling the roof-mounted PV-module temperature for common commercially used roofing materials to evaluate and characterize its power output under the equitorial climatic zone conditions of Belo Horizonte, Minas Gerais, Brazil [23]. This includes the experimental validation of the model under operating conditions in this locality.

\section{Mathematical modeling}

The model developed in this research is a dynamic model based on the total energy balance in the PV module. The energy balance is defined as follows [35]:

$$
q_{r}-q_{p}-P_{s}-C_{\mathrm{mod}} \frac{d T_{\mathrm{mod}}}{\mathrm{d} t}=0
$$

where $q_{r}$ is the solar radiation received at the front surface of the PV module, $q_{p}$ is the energy lost to the environment through the heat transfer mechanisms, $P_{s}$ is the output power generated by the $\mathrm{PV}$ module, $C_{\bmod }$ is the thermal capacity of the $\mathrm{PV}$ module, and $\frac{d T_{\bmod }}{\mathrm{d} t}$ is the time-rate of change of the temperature of the PV module.
The solar irradiance that reaches the front surface of the $\mathrm{PV}$ module is defined as [36]:

$$
q_{r}=\alpha G A
$$

where $\alpha$ is the absorbance of the photovoltaic module, $G$ is the solar irradiance that reaches the $\mathrm{PV}$ module, and $A$ is the area of the PV module.

The output power of the PV module is defined in terms of the voltage and current produced:

$$
P_{s}=V I
$$

The thermal capacity of the PV module is equal to the sum of the properties of the materials that constitute it:

$$
C_{\text {mod }}=\sum_{1}^{M} A d_{n} \rho_{n} C_{p, n}
$$

where $d_{n}$ is the thickness of the material, $\rho_{n}$ is the density, and $C_{p, n}$ the specific heat of the nth layer. The total number of layers in the module is specified by the parameter $M$.

The physical properties of the materials used in the photovoltaic module of this study are summarized in Table 1.

The three heat-transfer modes-conduction, convection, and radiation-are considered in mechanisms of heat-loss of the PV module to the environment. The simplified physical model of the crystalline silicon module used in the evaluations of this study is illustrated in Figure 2. The heat loss due to conduction through the aluminum structure of the module can be neglected since the contact surface between it and the PV module is very small [39]. Considering the remaining losses due to convection and radiation, the total loss is:

$$
q_{p}=q_{\mathrm{conv}}+q_{\mathrm{rad}}
$$

where $q_{\text {conv }}$ is the flow of heat dissipated by convection and $q_{\mathrm{rad}}$ is the flow of heat dissipated by radioactive exchange.

Thermal losses due to convection and radiation occur both at the front and at the rear of the PV module. In the case of convection, front-side and back-side losses are 
Table 1. Physical properties of the PV module materials [37,38].

\begin{tabular}{llllc}
\hline Material & Thickness $d(\mathrm{~m})$ & Specific heat $C_{p}(\mathrm{~J} / \mathrm{kg} \mathrm{K})$ & $\begin{array}{l}\text { Density } \rho \\
\left(\mathrm{kg} / \mathrm{m}^{3}\right)\end{array}$ & Thermal conductivity $k,(\mathrm{~W} / \mathrm{mK})$ \\
\hline Glass & 0.003 & $500[20]$ & $3000[20]$ & $1.8[29]$ \\
EVA & 0.0005 & $2090[3]$ & $960[3]$ & $0.35[28]$ \\
Photovoltaic Cell & 0.00025 & $677[20]$ & $2330[20]$ & $148[28]$ \\
Tedlar/Poliester & 0.0005 & $1250[20]$ & $1200[20]$ & $0.2[28]$ \\
\hline
\end{tabular}

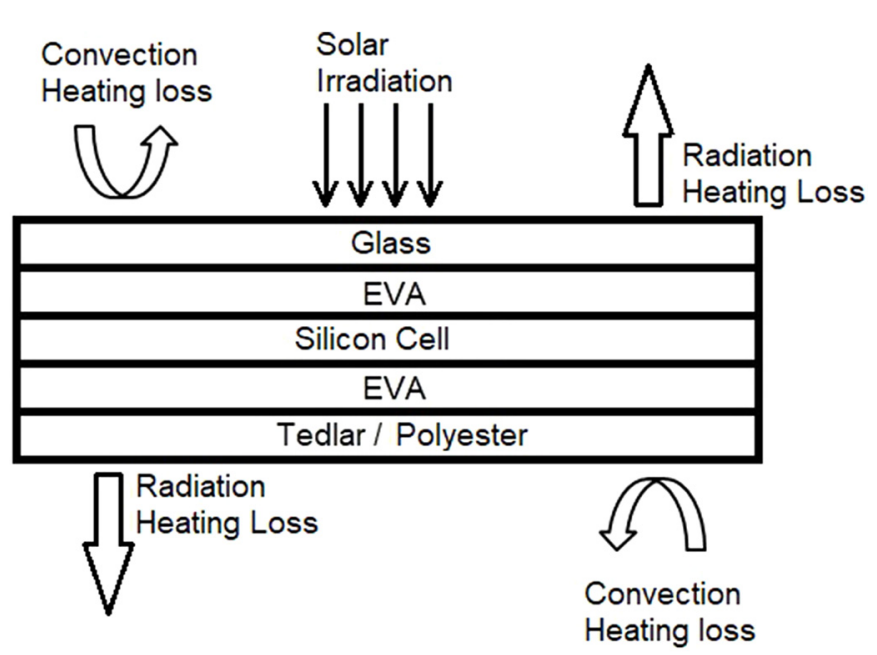

Fig. 2. Simplified physical model for photovoltaic module [36].

represented by the following relationships:

$$
\begin{gathered}
q_{\text {conv,front }}=\operatorname{Ah}_{\text {conv,front }}\left(T_{\text {front }}-T_{\mathrm{amb}}\right) \\
q_{\text {conv,back }}=\operatorname{Ah}_{\text {conv,back }}\left(T_{\text {tras }}-T_{\mathrm{amb}}\right)
\end{gathered}
$$

where $h_{\text {conv }}$ is the convection heat transfer coefficient calculated for the front and back of the photovoltaic module, $A$ is the area of the PV module, $T_{\text {front }}$ and $T_{\text {tras }}$ are the temperature of the front and back of the PV module respectively. $T_{\mathrm{amb}}$ is the ambient temperature. In this work $T_{\text {amb }}$ and $T_{\text {sky }}$ (sky temperature) are the same [36].

The calculation of the convective coefficient, $h_{\text {conv }}$ is complex because it depends on the environmental characteristics of the location where the module is installed - as well as on how the PV module is positioned on the roof, on the speed and orientation of the wind, and on the properties of the air that circulates near the PV module. The convective coefficient is calculated from the Nusselt number, for the front and the rear part of the PV module:

$$
h_{\mathrm{conv}}=\frac{\mathrm{Nu}_{\mathrm{conv}} k}{L}
$$

where $\mathrm{Nu}_{\text {conv }}$ is the Nusselt number calculated through empirical correlations, $k$ is the thermal conductivity of the air, and $L$ is the characteristic length of the PV module, which is calculated through the ratio between the area of the module and its perimeter.

The air properties required for the calculations will be obtained at the film temperature, and atmospheric pressure equal to $1 \mathrm{~atm}$. The temperature of the film is defined by:

$$
T_{\text {film }}=\frac{T_{(\text {front } / \text { tras })}+T_{\mathrm{amb}}}{2} .
$$

Typically, the temperature of the PV module is measured with a sensor positioned on the rear surface, so this measured value has to be corrected. The difference between the rear temperature and the front temperature of the PV module depends on the module's constituent materials, its thermal conductivity, and the incident irradiance. This has been treat by Bulag et al. [3], and the front and rear temperatures of the PV module can be related:

$$
T_{\text {front }}=T_{\text {tras }}+\frac{G_{T}}{G_{\text {ref }}} T
$$

where $G_{T}$ is the total irradiance that reaches the PV module, $\Delta T$ is the temperature difference between the front and rear of the module, and $G_{\text {ref }}$ is the reference solar irradiance, which is defined under standard measurement conditions as $1000 \mathrm{~W} / \mathrm{m}^{2}$ [40].

The literature provides reference values for $\Delta T$ that depend on the type of PV module assembly. Kratochvil et al. [28] considered an open-rack type assembly, in which the module support is opened allowing the air passage at the rear. They reported the temperature difference is $3{ }^{\circ} \mathrm{C}$, for an assembly type integrated to the building. The case in which there is no air circulation at the rear, the temperature difference is $1^{\circ} \mathrm{C}$. It is clear that this temperature difference will be influenced by the thermal characteristics of the PV module thermal capacity. There are basically three types of roof mounting for photovoltaic generators: leaning against the roof, integrated into the building, and separated by a distance from the roof.

The temperature difference between the front and back parts of the module can be measured experimentally for each type of assembly, and in the case of mounting away from the roof, the distance between generator and roof can also be varied in order to obtain values of $\Delta T$ for each distance between them. 
Both natural and forced convection have to be considered in the heat exchanges between the PV module and the environment. Depending on each situation, one will overlap the other. On days without wind, natural convection will dominate the heat loss process [41]. When there is wind, forced convection can dominate (depending on the wind characteristics). The convective coefficient for natural convection is:

$$
h_{\text {nat }}=\frac{\mathrm{Nu}_{\text {nat }} k}{L} .
$$

The Nusselt number for natural convection at the front of the PV module is calculated from [42]:

$$
\begin{aligned}
\mathrm{Nu}_{\text {nat,front }} & =0.14\left[\mathrm{Ra}^{\frac{1}{3}}-\left(\mathrm{Gr}_{\mathrm{cr}} \operatorname{Pr}\right)^{\frac{1}{3}}\right] \\
& +0.56\left(\mathrm{Gr}_{\mathrm{cr}} \operatorname{Prcos} \beta\right)^{\frac{1}{4}} .
\end{aligned}
$$

This expression is valid for the range: $10^{5}<\mathrm{Gr}_{\mathrm{cr}} \operatorname{Pr} \cos$ $\beta<10^{11}$, with $15^{\circ}<\beta<75^{\circ}$.

The critical Grashof number, $\mathrm{Gr}_{\mathrm{cr}}$, establishes the limit of passage between the laminar regime to the turbulent regime and can be found in the work of [43].

For the calculation of the forced convective coefficient the empirical correlation used is the one proposed by [40], and is given by:

$$
h_{\text {forc }}=\frac{0.931 \rho \nu \mathrm{C}_{\mathrm{p}} \operatorname{Re}^{\frac{1}{2}}}{\operatorname{LPr}^{\frac{2}{3}}} .
$$

The Reynolds number ( $\mathrm{Re}$ ) for a module mounted on the roof is:

$$
\operatorname{Re}=\frac{L}{v} v_{w} w_{a}
$$

where $v_{w}$ is the wind speed and $w_{a}$ is the wind adjustment coefficient that can be reported in the literature [35]. This coefficient adjusts the wind in relation to its direction and also takes into account the type of mounting of the generator on the roof. It is possible to obtain data on wind speed and direction through the GREEN PUC Minas (Energy Study Group) meteorological station [44], where the mathematical model validation tests have been performed. The Nusselt number, the ratio of convective to conductive heat transfer across a boundary, is:

$$
\mathrm{Nu}_{\text {forc }}=\frac{h_{\text {forc }} L}{k}
$$

The convective Nusselt number is calculated using natural and forced components [45]:

$$
\mathrm{Nu}_{\text {conv }^{3}} \approx \mathrm{Nu}_{\text {nat }^{3}}+\mathrm{Nu}_{\text {forc }^{3}} .
$$

The convective coefficient, $h_{\text {conv }}$, necessary to calculate the heat losses at the front and back of the module, can finally be obtained through the above ratio, so it is possible to calculate the total loss by convection $q_{\text {conv }}$.

The radiation heat loss basically follows the same principle in calculating the convective loss. The basic equation for calculating radiation losses is [46]:

$$
q_{\mathrm{rad}}=\sigma \varepsilon T^{4}
$$

where $\sigma$ is the Steffan-Boltzman constant, $\varepsilon$ is the emissivity of the surface, and $T$ is the surface temperature (in degrees Kelvin). The PV module emissivity lies between 0.85 and 0.91 [47].

From the basic equation of the heat transfer rate by radiation we can calculate the heat loss by radiation in the photovoltaic module:

$$
\begin{aligned}
\mathrm{q}_{\text {rad,front }}= & \mathrm{A}\left[\sigma \varepsilon_{\text {front }} \mathrm{F}_{\mathrm{fc}}\left(\mathrm{T}_{\text {front }}^{4}-\mathrm{T}_{\text {ceu }}^{4}\right)\right. \\
& \left.+\sigma \varepsilon_{\text {front }} \mathrm{F}_{\text {ft }}\left(\mathrm{T}_{\text {front }}^{4}-\mathrm{T}_{\text {tel }}^{4}\right)\right] \\
\mathrm{q}_{\text {rad,tras }}= & \mathrm{A}\left[\sigma \varepsilon_{\text {tras }} \mathrm{F}_{\text {tc }}\left(\mathrm{T}_{\text {tras }}^{4}-\mathrm{T}_{\text {ceu }}^{4}\right)\right. \\
& \left.+\sigma \varepsilon_{\text {tras }} \mathrm{F}_{\text {tt }}\left(\mathrm{T}_{\text {tras }}^{4}-\mathrm{T}_{\text {tel }}^{4}\right)\right]
\end{aligned}
$$

where the emissivity of the front and rear surfaces are $\varepsilon_{\text {front }}$ and $\varepsilon_{\text {tras }}$, respectively, the sky and roof temperatures are $T_{\text {ceu }}$ and $T_{\text {tel }}$ respectively, the factors $F_{\mathrm{fc}}, F_{\mathrm{ft}}, F_{\mathrm{tc}}$, and $F_{\mathrm{tt}}$ are called view factors and establish the relationship between the front surface and the sky, between the front surface and the roof, between the back surface and the sky, and between the back surface and the roof, respectively.

These factors are taken from the literature and are calculated for a photovoltaic module mounted on a roof and with a view angle (angle of the module in relation to the vertical) equal to $\beta$, according to the work of Jones and Underwood [48] The equations for calculating the view factors are taken from the work of Armstrong et al. [31].

The estimate of the temperature of the $T_{\text {tel }}$ roof depends mainly on the characteristics of the materials used, mainly on the thermal conductivity, absorptivity, and thermal capacity. An approximation for the roof temperature can be obtained through the work of Torres and Valkealahti [33]:

$$
T_{\text {tel }}=T_{\text {amb }}+a_{r} G_{h}
$$

where $a_{r}$ is the absorption coefficient of the roof, and $G_{h}$ is the irradiance incident in the horizontal plane.

However, this equation does not take into account the emissivity of the material, the inclusion of which may make the estimate of the roof temperature more accurate. Table 2 presents the absorptivity and emissivity of some roofs of common buildings in Brazil [49].

The irradiance incident on the horizontal plane can be directly measured or estimated using the equation proposed by Dominguez et al. [47]:

$$
G_{h}=\frac{G_{t} \operatorname{sen}(\gamma)}{\operatorname{sen}(\gamma+\beta)}
$$


Table 2. Absorptivity and emissivity for Brasil roof materials [49].

\begin{tabular}{lll}
\hline Surface type & $\mathbf{a}$ & $\boldsymbol{\varepsilon}$ \\
\hline Aluminum sheet (new and reflective) & 0.05 & 0.05 \\
Galvanized steel sheet (new and reflective) & 0.25 & 0.25 \\
Concrete & $0.65 / 0.80$ & $0.85 / 0.95$ \\
Clay tile & $0.75 / 0.80$ & $0.85 / 0.95$ \\
\hline
\end{tabular}

where $\gamma$ is the angle of elevation of the sun that will depend on the local latitude and longitude. The calculation of $\gamma$ can be found in the works developed by Duffie and Beckman [50]. Thus, the total heat loss can be obtained by adding the convective loss and the radiative loss.

The temperature of the module in relation to time is obtained by replacing the equations of $q_{r}, q_{p}, P_{s}$ and $C_{\text {mod }}$ in the proposed non-linear differential equation, resulting in:

\section{See equation (22) below.}

This equation has no analytical solution, but can be solved numerically by the Runge-Kutta method. The data of total irradiance GT, ambient temperature $T_{\mathrm{amb}}$, wind speed $(\mathrm{w})$, elevation angle $(\gamma)$, and output power $\left(\mathrm{P}_{\mathrm{s}}\right)$ will be used as input data for the solution of the problem.

\section{Valıdation of model with measured temperatures for roof-mounted pv generators}

Engineering Equation Solver (EES) software was used [51], incorporating the equations of the heat transfer model in order to define the temperature of PV module over different available types of roofing materials. This software was used because it is a common method employed by building energy designers (e.g., in conjunction with TRNSYS) and provides a comprehensive method to handle the complexity of the non-linear equations of this model. The most important parameters for studies with roof-mounted solar PV panel are roof absorptivity $\left(\mathrm{a}_{\mathrm{r}}\right)$, solar irradiance, ambient temperature ( $\mathrm{Ta}$ ) and wind speed coefficient, which, in turn, depends upon the materials of the roof, orientation of building roof, and its surroundings [45-47].

The common roof materials used in Belo Horizonte, Brazil, buildings are red ceramic, cement fiber, and galvanized steel. Initially, we carried out an online survey among companies and individual professional installers to gain information on the PV system installation configurations and parameters, especially the separation between the roof and the installed PV generator [52]. All residential locations surveyed had Si-PV module installations. For the
5 companies and 12 individual professional installers surveyed $41.2 \%$ answered that no distance between roof and PV generator is used in those installations, 29.4\% answered that $10 \mathrm{~cm}$ between PV generator and roof is used, $11.8 \%$ answered that it depends on the on what the installation location would permit (e.g., obstructions, ability to support the modules, security, etc.), $5.9 \%$ answered that the distance is $15 \mathrm{~cm}$ or more, and $11.7 \%$ answered that this "distance is not important". These data were used to define the distances from PV generator to roof for the experiments of this work, although mount directly on the roof was known to be very poor practice in most cases because of performance losses.

The model module temperature $T_{\text {mod }}$ (monitored at 1-minute intervals during each measurement day) was determined by solving equation (22) numerically using the Runge-Kutta method with EES software. The model shows an average error of $3 \%$ comparing with the experimental data. Figure 3 shows very good correlation between the measured and model predicted temperatures for each of the cases, with and average error of 3-4\% comparing the model with the experimental data. These data are used to determine the peak module temperature and the average module temperature for each of the roofing materials as a function of the module-roof separations.

Table 3 summarizes the experimental results for the 3 roofing materials as a function of the roof-module separation, corresponding to the data presented in Figure 3. The average temperature and the peak temperature in Table 3 were determinedtypical by averging the temperature from thermocouple sensors positioned at three places on the back of each PV module. The measurement was performed from 6:00 am to 16:30 pm for each pair of distance/material on days with best-sky conditions (with peak irradiances near $900 \mathrm{~W} / \mathrm{m}^{2}$ during this time of the year). Temperature was registered at 1-minute intervals, and the average module temperature cited in Table 3 was calculated from the data for the 6:00 am to 16:30 pm period of day. The peak temperature is the maximum temperature registered for the period. The maximum temperatures reached by the PV module occurred in all cases between 12:00-noon and 13:30 pm corresponding to the higher solar irradiance recorded. Some intermittent

$$
\begin{aligned}
\frac{d T_{\text {mod }}}{\mathrm{dt}} & =\frac{\alpha \mathrm{GA}-\mathrm{P}_{\mathrm{s}}-\mathrm{Ah}_{\text {conv, front }}\left(\mathrm{T}_{\text {front }}-\mathrm{T}_{\mathrm{amb})}-\mathrm{Ah}_{\text {conv, tras }}\left(\mathrm{T}_{\text {tras }}-\mathrm{T}_{\mathrm{amb}}\right)\right.}{\mathrm{C}_{\text {mod }}} \\
& \begin{array}{c}
\varepsilon_{\text {front }} \mathrm{F}_{\mathrm{fc}}\left(\mathrm{T}_{\text {front }}^{4}-\mathrm{T}_{\text {ceu }}^{4}\right)+\varepsilon_{\text {front }} \mathrm{F}_{\mathrm{ft}}\left(\mathrm{T}_{\text {front }}^{4}-\mathrm{T}_{\text {tel }}^{4}\right)+\varepsilon_{\text {tras }} \mathrm{F}_{\mathrm{bc}}\left(\mathrm{T}_{\text {tras }}^{4}-\mathrm{T}_{\text {ceu }}^{4}\right) \\
\mathrm{C}_{\text {mod }}
\end{array}
\end{aligned}
$$



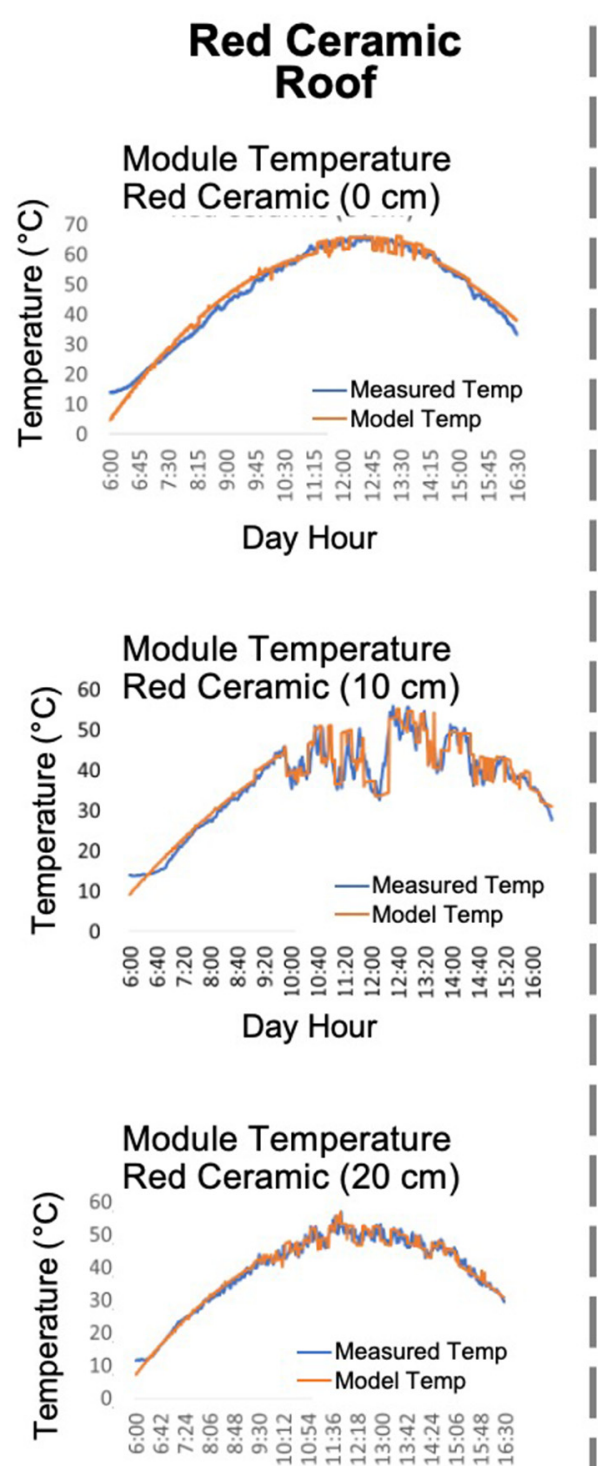

Day Hour

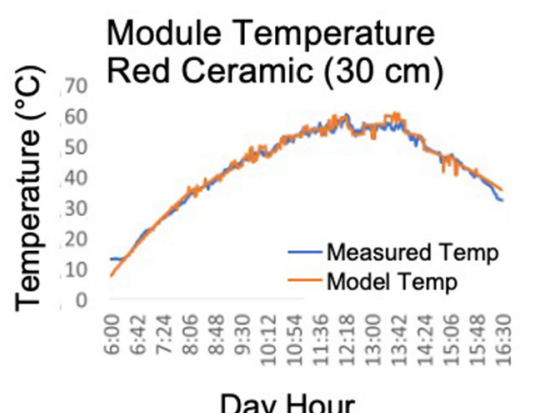

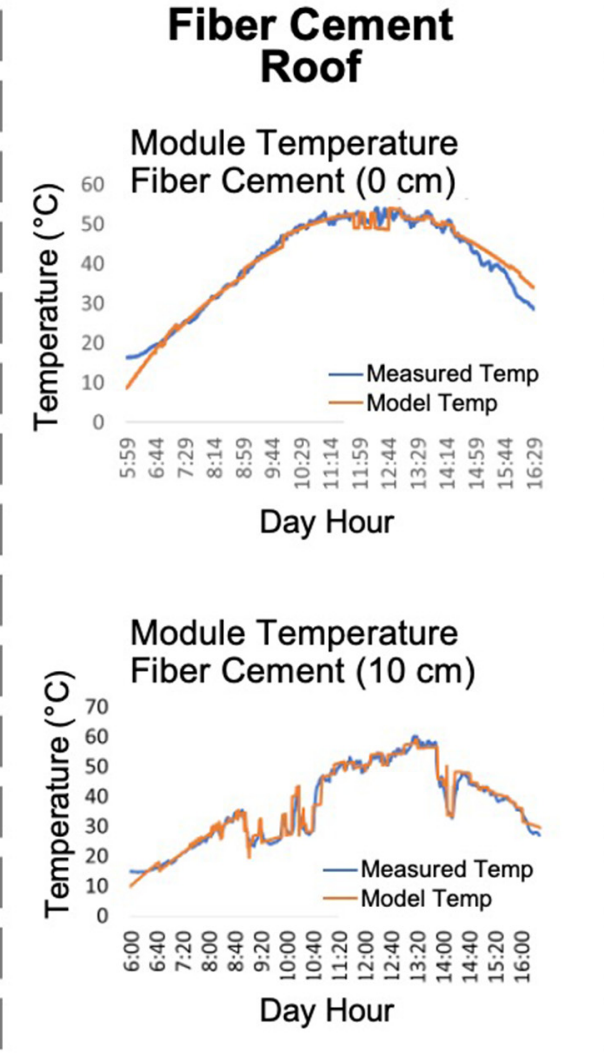
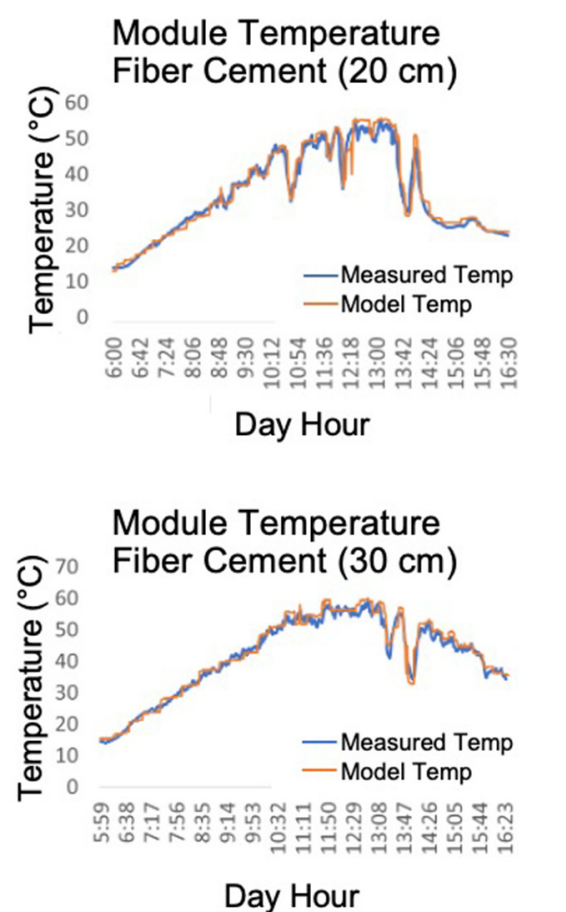

\section{Galvanized Steel Roof}

Module Temperature

Galvanized Steel $(0 \mathrm{~cm})$

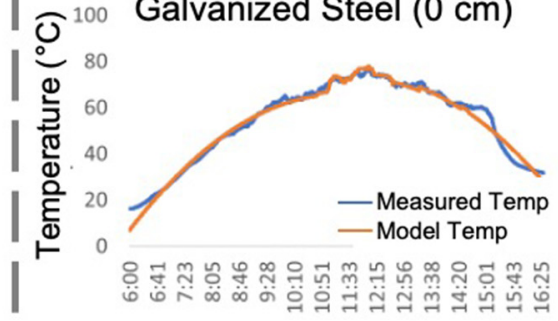

Day Hour

Module Temperature

Galvanized Steel $(10 \mathrm{~cm})$

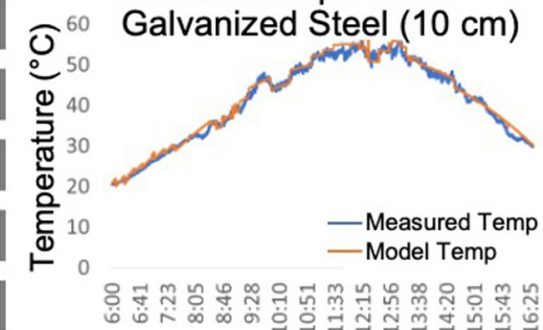

Day Hour

Module Temperature

Gavanized Steel $(20 \mathrm{~cm})$
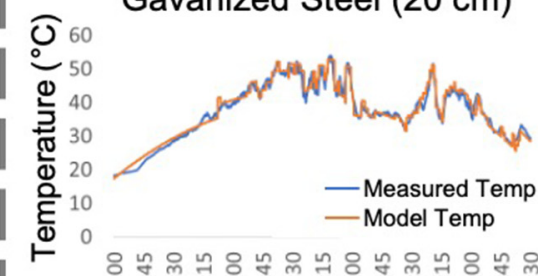

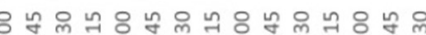
ம்

Day Hour

Module Temperature Gavanized Steel $(30 \mathrm{~cm})$

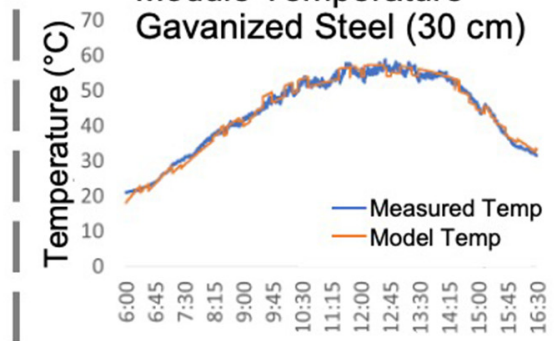

Day Hour

Fig. 3. Comparison of model and typical measured PV module temperatures as a function of hour of day and module-roof separations for red ceramic, fiber cement, and galvanized steel roofing materials. 
Table 3. Measured PV module temperature for 3 roof materials as a function of roof-module separation.

\begin{tabular}{|c|c|c|c|c|}
\hline \multirow[t]{2}{*}{ Roofing material } & \multicolumn{4}{|c|}{ Separation distance between roof and module } \\
\hline & $0 \mathrm{~cm}$ & $10 \mathrm{~cm}$ & $20 \mathrm{~cm}$ & $30 \mathrm{~cm}$ \\
\hline \multicolumn{5}{|l|}{ Red ceramic } \\
\hline Peak temperature $\left({ }^{\circ} \mathrm{C}\right)$ & 66.2 & 55.9 & 57.1 & 60.5 \\
\hline Average temperature $\left({ }^{\circ} \mathrm{C}\right)$ & 47.5 & 39.8 & 39.1 & 43.2 \\
\hline \multicolumn{5}{|l|}{ Cement fiber } \\
\hline Peak temperature $\left({ }^{\circ} \mathrm{C}\right)$ & 54.2 & 60.3 & 56.6 & 58.8 \\
\hline Average temperature $\left({ }^{\circ} \mathrm{C}\right)$ & 42.3 & 37.4 & 39.8 & 41.3 \\
\hline \multicolumn{5}{|l|}{ Galvanized steel } \\
\hline Peak temperature $\left({ }^{\circ} \mathrm{C}\right)$ & 76.9 & 55.6 & 53.8 & 58.7 \\
\hline Average temperature $\left({ }^{\circ} \mathrm{C}\right)$ & 55.5 & 41.1 & 39.3 & 41.8 \\
\hline
\end{tabular}
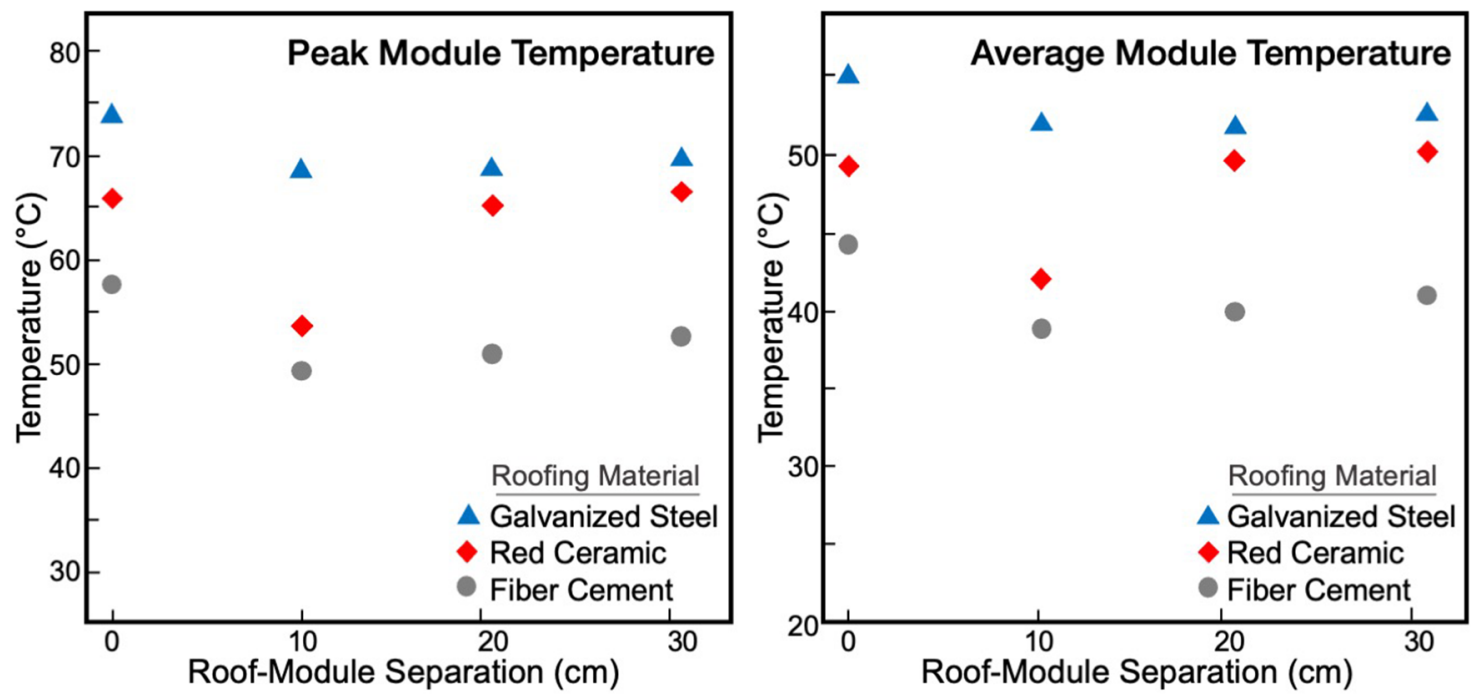

Fig. 4. Module temperatures as a function of room-module separation using same meterological and solar irradiance parameters in the model: (a) Peak module temperature (left) and (b) Average module temperature (right). This demonstrates the optimal separation of $10 \mathrm{~cm}$ for both the fiber cement and red tile roofing materials and higher optimal separation for the galvanized steel. Simulation also shows the differences in the module temperature, with fiber cement best and galvanized steel worst in considering either peak or average module temperature.

cloud cover was encountered, as can be observed in several of the characteristics in Figure 3. A feature of the model is that it takes into account the change in the irradiance and follows the corresponding change in roof and module temperature.

The measurement and model evaluation just discussed covers actual days that have difference in the solar irradiances due to intermittent cloud cover and meteorological conditions. To minimize these differences to provide a more balanced comparison of the 3 roof types, the model was run with data with no loss due to cloud cover and normalized to the same irradiance conditions. Figure 4 shows the differentiation between the roof types, with the better comparison between peak temperatures and average temperatures - with the fiber cement roof clearly better from the temperature of the module, and the separation of $10 \mathrm{~cm}$ the same for the fiber cement and the red tile.
The data show that for the three materials it is not recommended to install the generator without any distance between it and the roof, when this type of installation happens the temperatures are always higher, and consequently there are greater losses of energy generation. The ideal installation distance varies depending on the roof material. In the case of red ceramic, the ideal distance is between 10 and $20 \mathrm{~cm}$, for fiber cement the ideal installation distance of the PV module is around $10 \mathrm{~cm}$, and in the case of galvanized steel the ideal installation distance of the PV module is between 10 and $20 \mathrm{~cm}$. Interestingly, at the $30 \mathrm{~cm}$ distance between the PV module and the roof, an increase in temperature was recorded for all materials, which suggests that large installation distances are not desirable Figure 5 shows the field experiment to validate the mathematical model. 

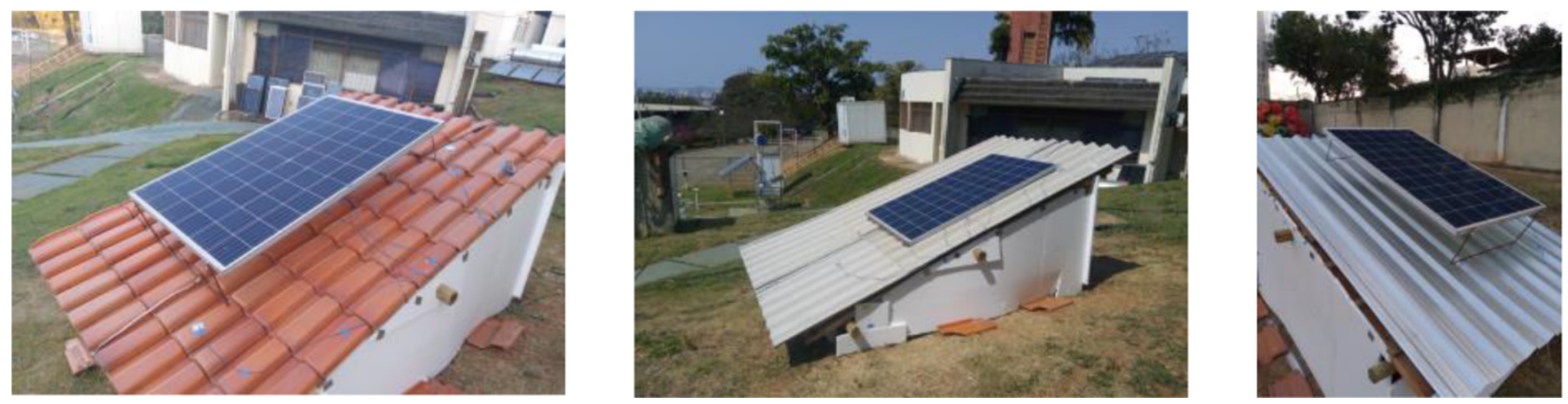

Fig. 5. PV module over a roof bench created to validate the mathematical model. From left to right are the three common Brazil roof materials: Red ceramic, fiber cement and galvanized steel.

These data confirm that the placement of the PV panel directly on the roof (i.e., 0-cm separation) is a configuration that should be avoided. This is a convention discouraged by most installers and suppliers to avoid the loss of power output due to potential higher panel temperatures [53]. Mounting with no separation results in the largest module temperatures for any of the 3 roofing materials. Although field (no-roof mounted) modules (mounted at the latitude near $20^{\circ}$ ) at this site operate typically $<50{ }^{\circ} \mathrm{C}$, direct roof mounting results in modules with temperatures $55^{\circ} \mathrm{C}$ to more than $70^{\circ} \mathrm{C}$. Though for the fiber cement thermal properties are best roof-panel operations in these studies, losses of at least 3\% to $4 \%$ in module power were observed over the reference fieldmounted modules. For the case of galvanized steel, the measured power losses were $10 \%$ to $15 \%$ for the modules mounted with no separation. Thus, those local installers $(41 \%)$ in the survey indicating that they mount directly on the roof are losing useful and considerable power for the consumers. There are, of course, also worries about longterm degradation or failure of these modules operating at higher temperatures under conditions that can be avoided. The best installation (separation) depends upon the roofing material. For example, the optimal separation is about $10 \mathrm{~cm}$ for the fiber cement and the red tile roofs and $20-30 \mathrm{~cm}$ for the galvanized steel. It should be noted that for all cases, the module temperature rises for separations greater than the optimal one due to increased radiation from larger exposure to roof areas. And in all cases, the roof mounted PV panels operate at higher temperatures than those that are field-mounted.

\section{Conclusions and summary}

This study has analyzed and evaluated the installation of crystalline-Si PV rooftop systems in the Brazil environment, based on common Brazil roofs, materials, and configurations. Modeling and experimental validation of the operating temperatures for these roof-mounted PV generators under Equitorial climate zone conditions in Belo Horizonte, Brazil. The major contributions include:
- An in-depth dynamic model has been developed in this research based on the total energy balance with the roofing material and the PV module to predict the operating temperature of the PV device. The special features of this model include consideration of the materials parameters of the roofing material and the PV panel, the heat transfer parameters, the solar resource and local climate conditions, and positioning of the panel with respect to the roof.

- The model is used evaluate the Si module temperature as a function of panel-roof separation for 3-common roofing materials used in Brazil under typical operating conditions. The optimal separations were found to be:

- Fiber Cement: $10 \mathrm{~cm}$

- Red Tile: $10 \mathrm{~cm}$

- Galvanized Steel: 20-30 cm.

- The model was validated by comparing it to temperature measurements for crystalline-Si panels mounted on the 3 -roofs under the local meteorological and solar conditions showing good correlations $(3-4 \%)$.

- Panels mounted directly onto the roof $(0 \mathrm{~cm}$ separation $)$ showed the highest operating temperatures during the day, typically peaking in the 12:00 to 13:00 time-of-day, corresponding to the peak irradiance time. The peak temperatures reached were highest for the panels on the galvanized steel roof and lowest on the fiber cement roof. This is due to the thermal properties of the roofing materials.

- Of the 3 roofs evaluated, the fiber cement was shown to be the best surface for mounting the PV panels due to its thermal capacity and transfer properties leading to the least heating of the solar panel at the lowest $(10 \mathrm{~cm})$ optimal separation distance. The red roof was second, with the same optimal separation but higher operating temperatures for the PV module. The galvanized steel roof required higher optimal separations with the panels always higher temperatures than for either of the other two roofs.

- Surveys conducted with installers and developers gave indications that there are concerns that roofs are being installed inappropriately. About half of these companies/ installers were either mounted directly on the existing roof 
or did not pay attention to any required separations- resulting in lower PV performance and potential longerrange degradation of these solar systems for the consumer.

We are in the process of providing the analyses of these studies to the installers and developers in this area. Though the prices for photovoltaic modules have decreased considerably over the last decade, they remain higher in Brazil due to import duties and lack of local manufacturing. Thus, the best-possible performance of these solar devices is critical to minimize costs to consumers. It is important to ensure consumer confidence through providing economic electricity costs and reliable products.

Acknowledgments. We acknowledge and sincerely appreciate the CEMIG/ANEEL R\&D Programme for funding the development of this research under R\&D project D638. Also, Universidade Federal de Viçosa (UFV) and PUC Minas through GREEN PUC Minas team and the Graduate Programme of Mechanical Engineering for providing technical assistance, guidance, and support.

\section{References}

1. Brazil Ministry of Mines and Energy [Plano Nacional de Energia 2050], Brazil's National Energy Plan 2050 - PNE 2050 (2021). http://antigo.mme.gov.br/web/guest/secreta rias/planejamento-e-desenvolvimento-energetico/publica coes/plano-nacional-de-energia-2050

2. H.A. Kazem, T. Khatib, K. Sopian, W. Elmenreich, Performance and feasibility assessment of a $1.4 \mathrm{~kW}$ roof top grid connected photovoltaic power system under desertic weather conditions, Energy Build. 82, 123-129 (2014)

3. C. Mokhtara, B. Negrou, N. Settou, A. AbBouferrouk, Y. Yao, Optimal design of grid-connected rooftop PV systems: an overview and a new approach with application to educational buildings in arid climates, Sustain. Energy Technolog. Assess. 47, 101468 (2021)

4. H.X. Li, Y. Zhang, D. Edwards, M.R. Hosseini, Improving the energy production of roof-top solar PV systems through roof design, Build. Simul. 13, 475-487 (2020)

5. M. Thebault, V. Clivillé, L. Berrah, G. Desthieux, Multicriteria roof sorting for the integration of photovoltaic systems in urban environments, Sustain. Cit. Soc. 60, 102259 (2020)

6. H. te Heesen, V. Herbort, M. Rumpler, Performance of rooftop PV systems in Germany from2012 to 2018, Solar Energy 194, 128-135 (2019)

7. A.H.A. Dehwah, M. Asif, Assessment of net energy contribution to buildings by rooftop photovoltaic systems in hot-humid climates, Renew. Energy 131, 1288-1299 (2019)

8. K. Sinapis, K. Tsatsakis, M. Dörenkämper, W.G.J.H.M. van Sark, Evaluation and analysis of selective deployment of power optimizers for residential PV systems, Energies 14, 811 (2021)

9. S.C.S. Costa, A.S.A.C. Diniz, L.L. Kazmerski, Solar energy dust and soiling R\&D progress: literature review update for2016, Renew. Sustain. Energy Rev. 82, 2504-2536 (2018)
10. H.A. Kazem, M.T. Chaichan et al., Evaluation of dust elements on photovoltaic module performance: an experimental study, Renew. Energy Environ. Sustain. J. 6, 2021 (2021)

11. M. Mani, R. Pillai, Impact of dust on solar photovoltaic (PV) performance: research status, challenges and recommendations. Renew. Sustain. Energy Rev. 14, 3124-3131 (2010)

12. T. Sarver, A. Al-Qaraghuli, L.L. Kazmerski, A comprehensive review of the impact of dust on the use of solar energy: history, investigations, results, literature, and mitigation approaches, Renew. Sustain. Energy Rev. 22, 698-733 (2013)

13. A.A. Kazem, M.T. Chaichan, H.A. Kazem, Dust effect on photovoltaic utilization in Iraq: review article, Renew. Sustain. Energy Rev. 37, 734-749 (2014)

14. H.A. Kazem, M.T. Chaichan, A.H. Alwaeli, K. Mani, Effect of shadows on the performance of solar photovoltaic, in Mediterranean Green Buildings $\&$ Renewable Energy, edited by A. Sayigh (Springer, Cham, 2017)

15. H.A. Kazem, M.T. Chaichan, A.H.A. Al-Waeli, K. Sopian, A.S.K. Darwish, Evaluation of dust elements on photovoltaic module performance: an experimental study, Renew. Energy Environ. Sustain. 6, 30 (2021)

16. D. Bernadette, M. Twizerimana, A. Bakundukize, B. Jean Pierre, N. Theoneste, Analysis of shading effects in solar PV system, Int. J. Sustain. Green Energy 10, 47-62 (2021)

17. K. Chiteka, R. Arora, S.N. Sridhara, C.C. Enweremadu, Influence of irradiance incidence angle and installation configuration on the deposition of dust and dust-shading on a photovoltaic array, Energy 119289 (2021)

18. J. Zhou, Z. Ahe, Q. Yi, Temperature distribution and back sheet role of polycrystalline silicon photovoltaic modules, J. Appl. Therm. Eng. 111, 1296-1303 (2017)

19. S.A.A. dos Santos, J.P.N. Torres, C.A.F. Fernandes, R.A.M. Lameirinhas, The impact of aging of solar cells on the performance of photovoltaic panels, Energy Convers. Manag. X 10, $100082(2021)$

20. H.A. Kazem, M.T. Chaichan, A.H.A. Al-Waeli, K. Sopian, Evaluation of aging and performance of grid-connected photovoltaic system northern Oman: seven years' experimental study, Solar Energy 207, 1247-1258 (2020)

21. J. Kim, M. Rabelo, S.P. Padi, H. Yousuf, E.-C. Cho, J. Yi, A review of the degradation of photovoltaic modules for life expectancy, Energies 14, 4278 (2021)

22. G. Pillai, A. Radity, M. Mani, P. Ramamurthy, Cell (module) temperature regulated performance of a building integrated photovoltaic system in tropical conditions, Renew. Energy 72, 140-148 (2014)

23. S.C.S. Costa, L.L. Kazmerski, A.S.A.C. Diniz, Impact of soiling on Si and CdTe PV modules: case study in different Brazil climate zones, Energy Convers. Manag. 10, 100084 (2021)

24. R. Ruther, R. do Nascimento, R.A. Campos, Performance assessment issues in utility-scale photovoltaics in warm and sunny climates, Renew. Energy Environ. Sustain. 2,35-41 (2017)

25. G.D. Buchan, Analytic modelling of solar radiation: driven temperature variations of outdoor surfaces, Appl. Math. Modelling. (1986). https://www.sciencedirect.com/science/ article/pii/0307904×8690020X

26. F. Ghani et al., On the influence of temperature on crystalline silicon solar cell characterisation parameters, Solar Energy 112, 437-445 (2015) 
27. J.H. Jo, T.P. Otanicar, A hierarchical methodology for the mesoscale assessment of building integrated roof solar energy systems, Renew. Energy 36, 2992-3000 (2011)

28. J.A. Kratochvil, W.E. Boyson, D.L. King, Photovoltaic Array Performance Model, Vol. 8. Sandia National Laboratory, Albuquerque, NM, and Livermore, CA, 2004. https://pvpmc.sandia.gov/modeling-steps/2-dcmodule-iv/point-value-models/sandia-pv-array-perfor mance-model/

29. L.W. Zhe, I.B. Yusoff, M.I. Misrun, A.B.A. Razak, S. Ibrahim, N.S.B. Zhubir, Investigation of solar panel performance based on different wind velocity using ANSYS, Indon. J. Electr. Eng. Comput. Sci. 1, 456-463 (2016)

30. J.C. Zhou et al., Temperature distribution and back sheet role of polycrystalline silicon photovoltaic modules, Appl. Thermal Eng. 111, 1296-1303 (2016)

31. S. Armstrong, W.G. Hurley, A thermal model for photovoltaic panels under varying atmospheric conditions, Appl. Therm. Eng. 30, 1488-1495 (2010)

32. B. Tuncel, T. Ozden, R.S. Balog et al., Dynamic thermal modelling of PV performance and effect of heat capacity on the module temperature, Case Stud. Therm. Eng. 22, 100754 (2020)

33. L.D. Torres, S. Valkealahti, Dynamic thermal model of solar PV systems under varying climatic conditions, Solar Energy 93, 183-194 (2013)

34. E. Skoplaki, J.A. Palyvos, On the temperature dependence of photovoltaic module electrical performance: a review of efficiency/power correlations, Solar Energy 83, 614-624 (2008)

35. A.S. Vaka, P. Talukdar, Novel inverse heat transfer technique for estimation of properties and location- specific process parameters of roof-mounte solar PV plants, Therm. Sci. Eng. Progr. 19, 100657 (2020)

36. A.L. Fahrenbruch, R.H. Bube, Fundamentals of Solar Cells: Photovoltaic Solar Cell Conversion, Academic Press, New York (1983)

37. S. Chander et al., A study on photovoltaic parameters of mono-crystalline silicon solar cell with cell temperature, Energy Reports 1, 104-109 (2015)

38. Manufacturer's specifications sheets

39. H.-F. Tsai, H.-L. Tsai, Implementation and verification of integrated thermal and electrical models for commercial PV modules, Solar Energy 86, 654-665 (2012)
40. A.P.C. Guimarães, Estudo solarimétrico com base na definição de mês padrão e sequência de radiação diária, Dissertação (Mestrado). Universidade Federal de Minas Gerais - Curso de Pós-Graduação em Engenharia Mecânica, 1995

41. R.S. Balog, Y. Kuai, G. Uhrhan, A photovoltaic module thermal model using observed insolation and meteorological data to support a long life, highly reliable module-integrated inverter design by predicting expected operating temperature, in 2009 IEEE Energy Convers. Congr. Expo. ECCE 2009, IEEE (2009) pp. 3343-3349

42. A. Bejan, A.D. Kraus, Heat Transfer Handbook, McGraw Hill, New York (2003), vol. 1

43. GREEN PUC Minas (Grupo de Estudos em Energia PUCMinas). https://ipuc.pucminas.br/green/index.html

44. F.P. Incropera, Fundamentals of Heat and Mass Transfer, John Wiley, New York (2007)

45. H.C. Hottel, A.F. Sarofim, Radiative Transfer, McGraw Hill Book Company, New York (1967)

46. M. Malinek, P. Kotoulek, A. Petrovic, T. Regrit, M. Bozikova, P. Hlavac, V. Cviklovic, M. Olejar, Modelling of photovoltaic module convective heat transfer coefficient, MendelNet 2016, 877-882 (2016)

47. A.D. Jones, C.P. Underwood, A thermal model for photovoltaic systems, Solar Energy 70, 349-359 (2001)

48. ABNT, Desempenho térmico de edificações Parte 2: Métodos de cálculo da transmitância térmica, da capacidade térmica, do atraso térmico e do fator solar de elementos e componentes de edificações. Brazil (2004)

49. A. Dominguez, J. Kleissl, J.C. Luvall, Effects of solar photovoltaic panels on roof heat transfer, Solar Energy 85, 2244-2255 (2011)

50. J.A. Duffie, W.A. Beckman, Solar Engineering of Thermal Processes, 3rd edn., John Wiley \& Sons, New York (2006)

51. Energy Equation Solver (EES) software is a general equatinsolving program that can numberically solve multiple coupled non-linear algebraic and differential equations. https://ees-64-bit-engineering-equation-solver.software.in former.com

52. R. DeGunther, Mounting solar panels, in Solar Power your Home for Dummies, 2nd ed. (Wiley, 2020) https://www. dummies.com/home-garden/green-living/energy-sources/ mounting-equipment-for-solar-panels

Cite this article as: Bernardo de Souza Guimarães, Lucas Farias, Delly Oliveira Filho, Lawrence Kazmerski, Antonia Sônia A. Cardoso Diniz, Roof-mounted photovoltaic generator temperatue modeling based on common brazil roofing materials, Renew. Energy Environ. Sustain. 7, 5 (2022) 